\title{
Handle old laryngoscopes with care
}

\author{
Shriram Vaidya, Suman Lata Gupta, Priya R, MVS Satya Prakash
}

Department of Anaesthesiology and Critical Care, JPMER, Puducherry, India

\section{Correspondence to} Dr Munaganuri Satya Prakash, munaganuri1975@yahoo.co.in

Accepted 4 November 2014

\section{DESCRIPTION}

A 30-year-old woman with fibroid uterus was operated on for myomectomy under general anaesthesia. Preoperative evaluation revealed adequate mouth opening, neck extension, thyromental distance and Mallampati grade 1. In the operating room, anaesthesia was induced with fentanyl and propofol under standard monitoring. Muscle relaxation was achieved with vecuronium. Laryngoscopy was attempted with a size 3 McIntosh laryngoscope blade after mask ventilating the patient for $3 \mathrm{~min}$. Laryngoscopy revealed a Cormack Lehane grade 3 view. External laryngeal manipulation with increased axial force along the laryngoscope handle was attempted. During this time, the laryngoscope blade along with the hinge piece separated from rest of the handle at the weld line. Fortunately, none of the batteries or other parts slipped into the patient's oropharynx. The patient was mask ventilated and laryngoscopy was attempted with another laryngoscope. Subsequent tracheal intubation was successful with help of a stylet. On closer examination of the damaged laryngoscope handle, breakage was found along the line where the knurled barrel of the handle was welded into the proximal cast fitting of the hinge piece (figures 1 and 2).

Failure of welding can be attributed to laryngoscope handle wear; the laryngoscope had clearly been

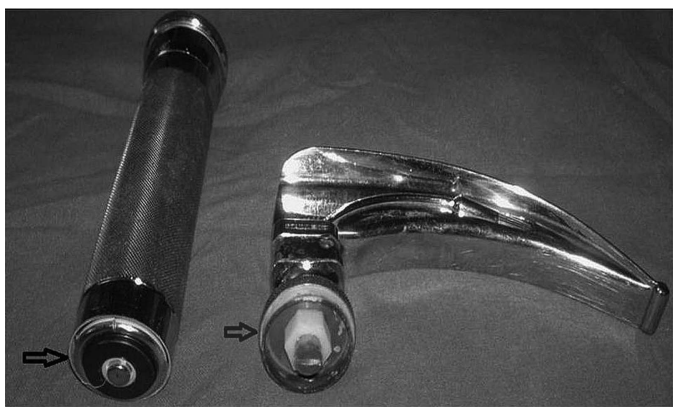

Figure 1 Hinge piece separated from knurled barrel of handle.

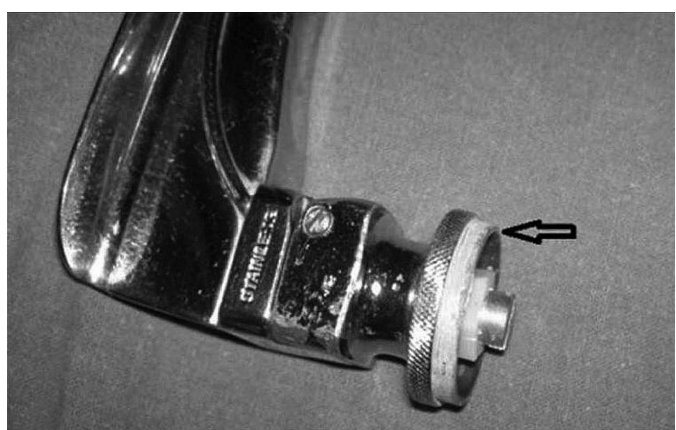

Figure 2 Failed welding at hinge piece. in use for many years. The weld line between the hinge piece and knurled barrel of the handle acts as a fulcrum and is subjected to a force of 10-30 newton during laryngoscopy. This force can reach 100 newton during a difficult laryngoscopy and in our case could have caused the failure of the welding. ${ }^{1}$ Breakage at hinge and ingestion and loss of rivet in a MacCoy blade have been reported earlier. ${ }^{2}$

\section{Learning points}

- Besides checking for the functional status of laryngoscopes (light intensity, fitting bulb), integrity of blade and handle assembly should also be tested by applying force in extended working position.

- Manufacturer-specified instructions should be strictly adhered to while cleaning and sterilising laryngoscopes. Healthcare Infection Control Practices Advisory Committee (HICPAC) guidelines for disinfection and sterilisation in healthcare facilities as proposed by Centres for Disease Control and Prevention categorise laryngoscope blades as semicritical items that need to be subjected to high level disinfection for exposure time of $12-20 \mathrm{~min}$ at $\geq 20^{\circ} \mathrm{C}$. Among the recommended disinfectants, hydrogen peroxide $7.5 \%$, hydrogen peroxide $1 \%$ with peracetic acid $0.08 \%$ and hypochlorite are known to corrode metal instruments. However, no specific category has been assigned to laryngoscope handles. Hence, unless contaminated by oropharyngeal secretions, laryngoscope handles could be considered as non-critical items and subjected to intermediate to low level sterilisation with exposure time of $\geq 1$ min using ethyl or isopropyl alcohol (70-90\%), sodium hypochlorite (5.25-6.15\%), phenolic germicidal detergent solution, iodophor germicidal detergent solution or quaternary ammonium germicidal detergent solution-none of which produce significant corrosion of metals - to minimise wear and tear.

- Institutes should implement a system of tracking the years of usage of individual laryngoscopes and regularly inspect and replace faulty equipment.

- A second working blade and handle should be available in the operation theatre. With these small measures, potential complications and trauma to the patient's airway can be avoided.

Contributors SV conducted the case, helped by PR; SLG and MSP reacted to the incident and arranged for equipment during the incident; and SV and SLG wrote the manuscript.

Competing interests None. 
Patient consent Obtained.

Provenance and peer review Not commissioned; externally peer reviewed.

\section{REFERENCES}

1 Rocco M, Chatwani A, Shupak R. Laryngoscope handle malfunction. Anesthesiology 1986;65:107.
2 Jain $A$, Naithani $M$, Chaudhary $Z$, et al. Rare iatrogenic airway foreign body: the rivet from the fulcrum of the McCoy laryngoscope blade. Indian J Anaesth 2012;56:301.

3 Rutala WA, Weber DJ. Healthcare Infection Control Practices Advisory Committee (HICPAC). Guideline for Disinfection and Sterilization in Healthcare Facilities. 2008. http://www.cdc.gov/ncidod/dhqp/pdf/guidelines/Disinfection_Nov_ 2008.pdf

Copyright 2014 BMJ Publishing Group. All rights reserved. For permission to reuse any of this content visit http://group.bmj.com/group/rights-licensing/permissions.

BMJ Case Report Fellows may re-use this article for personal use and teaching without any further permission.

Become a Fellow of BMJ Case Reports today and you can:

- Submit as many cases as you like

- Enjoy fast sympathetic peer review and rapid publication of accepted articles

- Access all the published articles

- Re-use any of the published material for personal use and teaching without further permission

For information on Institutional Fellowships contact consortiasales@bmjgroup.com

Visit casereports.bmj.com for more articles like this and to become a Fellow 